\title{
Genetic structure of Africanized honeybee populations (Apis mellifera L.) from Brazil and Uruguay viewed through mitochondrial DNA COI-COIl patterns
}

\author{
T Collet $^{1}$, KM Ferreira ${ }^{1}$, MC Arias ${ }^{2}$, AEE Soares ${ }^{3}$ and MA Del Lama ${ }^{1}$ \\ ${ }^{1}$ Departamento de Genética e Evolução, Universidade Federal de São Carlos, São Carlos, São Paulo, Brazil; ${ }^{2}$ Departamento de Biologia, \\ Instituto de Biociências, Universidade de São Paulo, São Paulo, Brazil and ${ }^{3}$ Departamento de Genética, Faculdade de Medicina de \\ Ribeirão Preto, Universidade de São Paulo, Ribeirão Preto, São Paulo, Brazil
}

\begin{abstract}
Mitochondrial genotypes of Africanized honeybees from Brazil and Uruguay were surveyed by Dral restriction of the $\mathrm{COI-COII} \mathrm{region.} \mathrm{Eleven} \mathrm{mitotypes} \mathrm{were} \mathrm{found,} \mathrm{three} \mathrm{of}$ which had not previously been described (A28-A30). Out of 775 samples (725 from Brazil, 50 from Uruguay), 197 were A1 and 520 were A4. A1 frequency increases toward the north of Brazil, whereas A4 frequency increases toward the south, a pattern echoing the African distribution. The origin of
\end{abstract}

the A4 and most of the A1 African patterns can be attributed to the introduction of Apis mellifera scutellata into Brazil in 1956. The A29 and A30 patterns have the P1 sequence observed in many Iberian Peninsula samples, which represent the traces of the introductions into Brazil and Uruguay by settlers.

Heredity (2006) 97, 329-335. doi:10.1038/sj.hdy.6800875; published online 6 September 2006

Keywords: Africanized bees; mtDNA variation; COI-COII patterns; population structure

\section{Introduction}

Since 1957, hybridization has been occurring in the Americas between the newly introduced African bees and the resident European bees present in Brazil since 19th century. This process is known as Africanization. The study of Africanization requires the development of methods for identifying a European or African origin of the bees, and for detecting changes in the genetic composition of the newly resulting populations.

Morphometric and allozymic evidence has been used to estimate the contribution of European and African alleles to the genetic makeup of the Africanized bee populations of South America. According to Lobo et al. (1989) and Del Lama et al. (1990), up to 20-30\% of enzyme genes of the Africanized populations of Brazil, Uruguay and Central America have a European origin. On the other hand, the mitochondrial DNA (mtDNA) of these populations predominantly has the African scutellata pattern (Hall and Muralidharan, 1989; Hall and Smith, 1991; Rotta, 1999). Nearly 97\% of the colonies from Brazil, Venezuela, Honduras and Mexico have mtDNA characteristic of Apis mellifera scutellata (Smith et al., 1989).

Correspondence: Dr MA Del Lama, Departamento de Genética e Evolução, Universidade Federal de São Carlos, Rodovia Washington Luís Km 235, São Carlos, São Paulo 13565-905, Brazil.

E-mail:dmdl@power.ufscar.br

Received 4 January 2006; revised 23 June 2006; accepted 28 June 2006; published online 6 September 2006
Hall and Smith (1991) suggest that the African mtDNA of neotropical populations could include the patterns iberiensis/intermissa introduced by Spanish and Portuguese settlers. However, on the basis of an unmapped polymorphic HinfI fragment, they concluded that colonies from Mexico, Venezuela and Brazil had the scutellata pattern. They considered it improbable that a colony identified as neotropical African has a non-scutellata origin. Similarly, the cytb-BglII data also demonstrate that all but $3-5 \%$ of the Africanized swarms have a scutellata pattern (Hall and Muralidharan, 1989).

The presence of European nuclear genes and an exclusively African mtDNA pattern in the Africanized populations has been explained by asymmetric flow of these markers in the hybrid population.

DraI restriction patterns of the COI-COII mtDNA region have proved to be the best tool for characterizing the lineages designated $\mathrm{A}, \mathrm{M}, \mathrm{C}$ and $\mathrm{O}$ A. mellifera from several areas of the world (De la Rúa et al., 1998, 2001a, b; Franck et al., 1998, 2000, 2001). Sheppard et al. (1999) analyzed on the basis of A1 pattern, suggest the COICOII region of colonies from Argentina and, suggest that the mtDNA considered as African has an intermissa origin. This finding would seem to demonstrate that the Africanized colonies have a more diverse maternal origin than the $A . m$. scutellata introduction in Brazil in 1956.

This paper describes the distribution of the COI-COII DraI in samples from Brazil and Uruguay. Samples from Spain and Italy were also included for comparison on with the African patterns. 


\section{Materials and methods}

\section{Samples and DNA extraction}

Apis mellifera samples from Brazil, Italy, Spain and Uruguay were analyzed. The origin of the colonies sampled is shown in Table 1. Samples included 725 colonies from 39 localities of Brazil, 50 colonies from six localities in Uruguay, 36 colonies from Italy (Milan region) and four colonies from the Galician region (Spain). Bees were caught and kept at $-20^{\circ} \mathrm{C}$ until use. Total DNA was extracted from the thorax of one adult worker of each colony using the phenol-chloroform method (Sheppard and McPheron, 1991).

\section{Polymerase chain reaction amplification and endonuclease digestion}

Mitochondrial analysis was carried out on a polymerase chain reaction (PCR) produced from the intergenic COICOII region according to Garnery et al. (1992). An aliquot of the PCR product was electrophoresed in $6 \%$ polyacrylamide gels stained with silver. Two microliters of the remaining amplified DNA were digested with $1 \mathrm{U}$ of

Table 1 Distribution of the studied Apis mellifera populations from Brazil, Uruguay, Spain and Italy with the number of mitochondrial haplotypes observed

\begin{tabular}{|c|c|c|c|c|c|c|c|c|c|c|c|c|c|c|}
\hline Country & Locality & Latitude & Longitude & $A 1$ & $A 4$ & $A 26$ & $A 28$ & $A 29$ & $A 30$ & $\mathrm{C} 1$ & M3 & M4 & M6 & M7 \\
\hline \multirow[t]{40}{*}{ Brazil } & S. Livramento & $30^{\circ} 53^{\prime} \mathrm{S}$ & $55^{\circ} 51^{\prime} \mathrm{W}$ & & 8 & & & & & & & & & \\
\hline & Alegrete & $29^{\circ} 46^{\prime} \mathrm{S}$ & $55^{\circ} 47^{\prime} \mathrm{W}$ & 1 & 7 & & & & & & & & & \\
\hline & Santa Maria & $29^{\circ} 41^{\prime} \mathrm{S}$ & $53^{\circ} 48^{\prime} \mathrm{W}$ & 4 & 5 & & & & 1 & & & & & \\
\hline & Eldorado do Sul & $29^{\circ} 25^{\prime} \mathrm{S}$ & $51^{\circ} 58^{\prime} \mathrm{W}$ & 6 & 17 & 1 & 1 & & & 1 & & & & \\
\hline & São Joaquim & $28^{\circ} 17^{\prime} S$ & $49^{\circ} 55^{\prime} \mathrm{W}$ & 1 & 22 & 2 & 2 & & & & & & & \\
\hline & Lagoa Vermelha & $28^{\circ} 12^{\prime} \mathrm{S}$ & $51^{\circ} 31^{\prime} \mathrm{W}$ & 2 & 19 & & & & & & & & & \\
\hline & Florianópolis & $27^{\circ} 35^{\prime} \mathrm{S}$ & $48^{\circ} 32^{\prime} \mathrm{W}$ & 1 & 17 & & & & & 2 & & & & \\
\hline & Blumenau & $26^{\circ} 55^{\prime} \mathrm{S}$ & $49^{\circ} 03^{\prime} \mathrm{W}$ & 1 & 19 & & & & 1 & 1 & & & & \\
\hline & Curitiba & $25^{\circ} 25^{\prime} \mathrm{S}$ & $49^{\circ} 16^{\prime} \mathrm{W}$ & 2 & 10 & & & & & & & & & \\
\hline & Maringá & $23^{\circ} 25^{\prime} \mathrm{S}$ & $51^{\circ} 56^{\prime} \mathrm{W}$ & & 24 & & & & & 1 & & & & \\
\hline & Bom Jardim & $22^{\circ} 09^{\prime} \mathrm{S}$ & $42^{\circ} 25^{\prime} \mathrm{W}$ & 6 & 8 & & & & & 1 & & & & \\
\hline & Luís Antônio & $21^{\circ} 33^{\prime} \mathrm{S}$ & $47^{\circ} 42^{\prime} \mathrm{W}$ & 4 & 42 & & & & & & & & & \\
\hline & Viçosa & $20^{\circ} 45^{\prime} \mathrm{S}$ & $42^{\circ} 52^{\prime} \mathrm{W}$ & 5 & 14 & & & 1 & & & & & & \\
\hline & Miranda & $20^{\circ} 14^{\prime} \mathrm{S}$ & $56^{\circ} 22^{\prime} \mathrm{W}$ & 16 & 10 & & & & & & & & & \\
\hline & D. Indaiá & $19^{\circ} 27^{\prime} \mathrm{S}$ & $45^{\circ} 36^{\prime} \mathrm{W}$ & & 18 & 2 & & & & & & & & \\
\hline & Corumbá & $19^{\circ} 00^{\prime} \mathrm{S}$ & $57^{\circ} 39^{\prime} \mathrm{W}$ & 7 & 10 & & & & & & & & & \\
\hline & G. Valadares & $18^{\circ} 51^{\prime} \mathrm{S}$ & $41^{\circ} 56^{\prime} \mathrm{W}$ & 6 & 8 & & & 2 & & & & & & \\
\hline & Goiânia & $16^{\circ} 40^{\prime} \mathrm{S}$ & $49^{\circ} 15^{\prime} \mathrm{W}$ & 4 & 16 & & & & & & & & & \\
\hline & P. Araguaia & $15^{\circ} 50^{\prime} \mathrm{S}$ & $52^{\circ} 00^{\prime} \mathrm{W}$ & 5 & 12 & & & & & & & & & \\
\hline & Cuiabá & $15^{\circ} 35^{\prime} \mathrm{S}$ & $56^{\circ} 05^{\prime} \mathrm{W}$ & 7 & 12 & & & & & 1 & & & & \\
\hline & Salvador & $12^{\circ} 58 \mathrm{~S}$ & $38^{\circ} 30^{\prime} \mathrm{W}$ & 3 & 3 & & & & & & & & & \\
\hline & Conde & $11^{\circ} 48^{\prime} \mathrm{S}$ & $37^{\circ} 36^{\prime} \mathrm{W}$ & 1 & 4 & & & & & & & & & \\
\hline & Gurupi & $11^{\circ} 43^{\prime} \mathrm{S}$ & $49^{\circ} 04^{\prime} \mathrm{W}$ & & 12 & 2 & & 1 & & & & & & \\
\hline & Buquim & $11^{\circ} 08^{\prime} \mathrm{S}$ & $37^{\circ} 37^{\prime} \mathrm{W}$ & 3 & 8 & & & & & & & & & \\
\hline & Tucano & $10^{\circ} 57^{\prime} \mathrm{S}$ & $38^{\circ} 47^{\prime} \mathrm{W}$ & 9 & 7 & & & & 2 & & & & & \\
\hline & Aracaju & $10^{\circ} 54^{\prime} \mathrm{S}$ & $37^{\circ} 04^{\prime} \mathrm{W}$ & 5 & 4 & & & & & & & & & \\
\hline & Ouro P. Oeste & $10^{\circ} 44^{\prime} \mathrm{S}$ & $62^{\circ} 12^{\prime} \mathrm{W}$ & 4 & 16 & 1 & & & & & & & & \\
\hline & Guaraí & $8^{\circ} 50^{\prime} \mathrm{S}$ & $48^{\circ} 30^{\prime} \mathrm{W}$ & 11 & 8 & & & 1 & & & & & & \\
\hline & Recife & $8^{\circ} 03^{\prime} \mathrm{S}$ & $34^{\circ} 52^{\prime} \mathrm{W}$ & 5 & 10 & & & & & & & & & \\
\hline & N. Olinda & $7^{\circ} 37^{\prime} \mathrm{S}$ & $37^{\circ} 20^{\prime} \mathrm{W}$ & 7 & 11 & & & & 1 & & & & & \\
\hline & Araripina & $7^{\circ} 34^{\prime} \mathrm{S}$ & $40^{\circ} 29^{\prime} \mathrm{W}$ & 6 & 15 & & & & 3 & & & & & \\
\hline & Picos & $7^{\circ} 04^{\prime} \mathrm{S}$ & $41^{\circ} 28^{\prime} \mathrm{W}$ & 11 & 6 & & & 1 & & & & & & \\
\hline & B. Corda & $5^{\circ} 30^{\prime} \mathrm{S}$ & $45^{\circ} 14^{\prime} \mathrm{W}$ & 6 & 10 & & & & & & & & & \\
\hline & Mossoró & $5^{\circ} 11^{\prime} \mathrm{S}$ & $37^{\circ} 20^{\prime} \mathrm{W}$ & 7 & 11 & 2 & & & & & & & & \\
\hline & Manaus & $3^{\circ} 06^{\prime} \mathrm{S}$ & $60^{\circ} 01^{\prime} \mathrm{W}$ & 9 & 13 & & & & & & & & & \\
\hline & São Luís & $2^{\circ} 31^{\prime} \mathrm{S}$ & $44^{\circ} 18^{\prime} \mathrm{W}$ & 3 & 9 & 1 & & 1 & 4 & & & & & \\
\hline & Belém & $1^{\circ} 27^{\prime} \mathrm{S}$ & $48^{\circ} 30^{\prime} \mathrm{W}$ & & 20 & & & & & & & & & \\
\hline & Boa Vista & $2^{\circ} 49^{\prime} \mathrm{N}$ & $49^{\circ} 03^{\prime} \mathrm{W}$ & 20 & 18 & & & 1 & & & & & & \\
\hline & Aldeia Contão & $3^{\circ} 27^{\prime} \mathrm{N}$ & $60^{\circ} 26^{\prime} \mathrm{W}$ & 5 & 3 & & & & & & & & & \\
\hline & Total & & & 193 & 486 & 11 & 3 & 8 & 17 & 7 & & & & \\
\hline \multirow[t]{7}{*}{ Uruguay } & Montevidéo & $34^{\circ} 56^{\prime} S$ & $56^{\circ} 14^{\prime} \mathrm{W}$ & & 4 & & & & & & & 1 & & \\
\hline & Rocha & $34^{\circ} 00^{\prime} \mathrm{S}$ & $54^{\circ} 00^{\prime} \mathrm{W}$ & & 10 & & & 1 & & & & & & \\
\hline & O. de Lavalle & $33^{\circ} 18^{\prime} \mathrm{S}$ & $56^{\circ} 21^{\prime} \mathrm{W}$ & & 2 & & & & 1 & 3 & & & & \\
\hline & Paysandu & $32^{\circ} 19^{\prime} \mathrm{S}$ & $58^{\circ} 06^{\prime} \mathrm{W}$ & 1 & 3 & & & & & 1 & & & & \\
\hline & Mello & $32^{\circ} 07^{\prime} \mathrm{S}$ & $54^{\circ} 41^{\prime} \mathrm{W}$ & 2 & 12 & & & & & & & & & \\
\hline & Durazno & $31^{\circ} 01^{\prime} \mathrm{S}$ & $56^{\circ} 57^{\prime} \mathrm{W}$ & 1 & 3 & 1 & & & 4 & & & & & \\
\hline & Total & & & 4 & 34 & 1 & & 1 & 5 & 4 & & 1 & & \\
\hline \multirow[t]{3}{*}{ Italy } & Meda & & & & & & & & & 14 & 3 & & & 5 \\
\hline & Pozzone & & & & & & & & & 7 & 1 & & & 5 \\
\hline & Seregno & & & & 1 & & & & & & & & & \\
\hline Spain & Galícia & & & & & & & & & & & & 1 & 2 \\
\hline
\end{tabular}

Brazilian and Uruguayan localities are distributed according to their latitudes. 
DraI enzyme (Promega, Madison, WI, USA) in a $20 \mu 1$ mixture. The resulting fragments were visualized in $12 \%$ polyacrylamide gels stained with silver. Haplotypes were determined according to the patterns scored by Garnery et al. (1993).

A Pearson test was performed to examine the correlation between the frequency of A1 mitotype and latitude using the BioEstat 3.0 program (Ayres et al., 2003).

\section{DNA cloning and sequencing}

PCR fragments from each distinct restriction pattern were cloned using the T-Easy cloning kit (Promega) and used to transform competent Escherichia coli DH-5 $\alpha$ cells. Positive clones were selected. The recombinant vectors were recovered and sequenced following the protocols suggested by Applied Biosystems (www.appliedbiosystems.com). An automated sequencer ABI-3100 (Applied Biosystems, Foster City, CA, USA) was used to sequence the samples. Two clones of each pattern were sequenced from both directions. The sequence data were analyzed by multi-alignment with the Multalin program (www. toulouse.inra.fr/multalin).

\section{Results}

Analysis of the 815 colonies from Brazil, Italy, Spain and Uruguay revealed 11 different mitotypes for the COICOII region, eight of which were previously described (Garnery et al., 1993; Franck et al., 2001) and three A mitotypes not previously reported (A28, A29 and A30) (Table 1; Figure 1). Figure 2 displays restriction maps and fragment lengths.

The observed patterns were classified by means of the $P$ sequence $\left(P_{0}, P_{1}\right.$ or $\left.P\right)$ and the number of $Q$ sequences (Figure 3 ). By comparison with the sequences $\mathrm{P}$ and $\mathrm{Q}$ presented by Franck et al. (2001) and Franck et al. (2000), respectively, our sequences were characterized as belonging to the A lineage (six mitotypes), C (one mitotype) and $M$ (four mitotypes). The new $A$ types have three (A28 and A29) and two (A30) Q sequences, with distinct restriction patterns. Pattern A28 showed the $P_{0}$ sequence characteristic of most $A$ lineage patterns. Sequence $P_{1}$ was observed in A29 and A30. This sequence includes a $15 \mathrm{bp}$ deletion and characterizes the mitotypes of $\mathrm{A}$ lineages from the African-Atlantic coast (Franck et al., 2001) and Iberian Peninsula (Garnery et al., 1995; De la Rúa et al., 1998; Franck et al., 2001).

The main patterns observed in Brazil are the African A4 (68\%) and A1 (26\%) haplotypes (Figure 4). The proportion of A4 mitotype is higher in populations from Central and Southern Brazil (being also the most common in Uruguayan samples), whereas the frequency of A1 pattern increases toward the north. The Pearson test indicated a negative and significant correlation between the A1 frequency and latitude $(r=-0.561$; $P<0.0001)$. The C1 mitotype is present in some southern populations (Table 1), whereas the mellifera pattern was not observed in the Brazilian colonies and only one Uruguayan sample showed the M4 pattern.

Seven populations from Brazil and one from Uruguay contained A26 (as determined by restriction patterns and their $\mathrm{P}$ sequences) (Figure 2), a mitotype also observed by Franck et al. (2001) in the Southwest African A. m. adansonii.

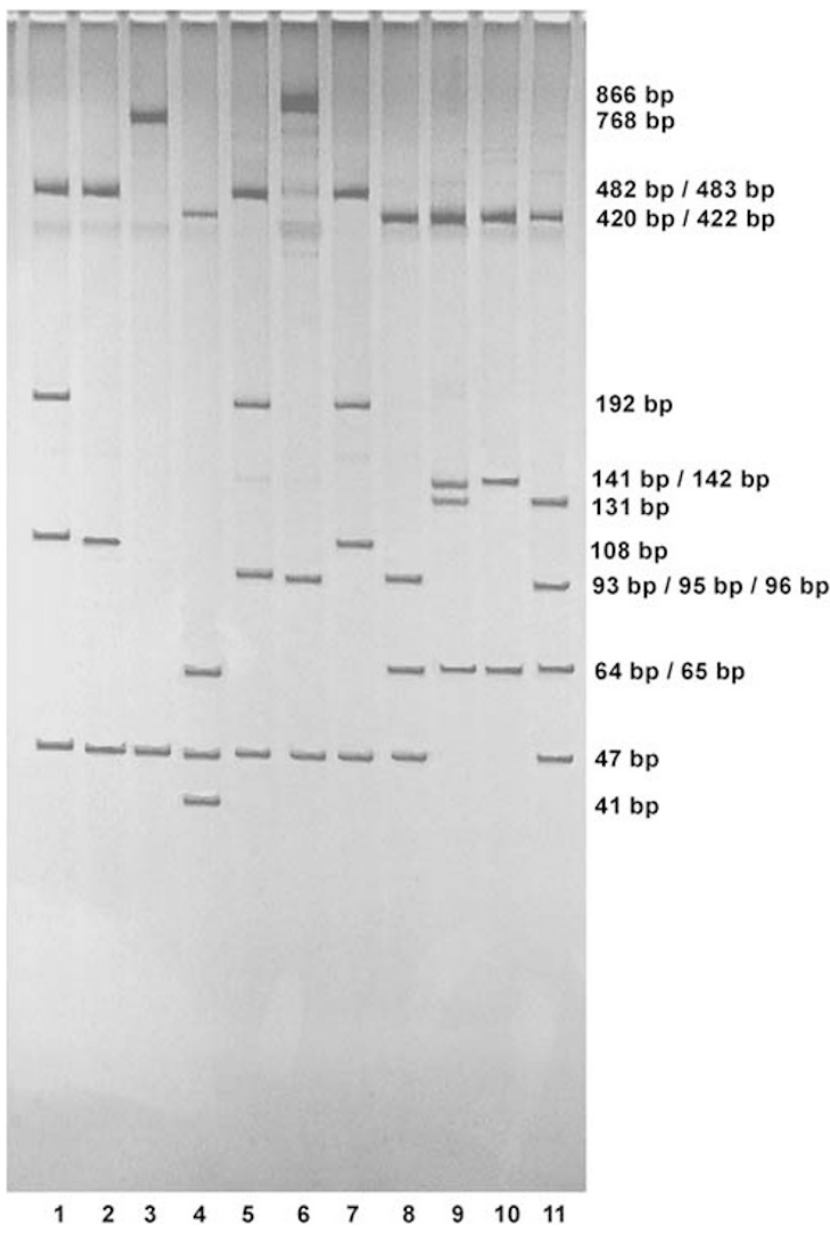

Figure $1 \mathrm{DraI}$ restriction patterns of the COI-COII mtDNA region of A. mellifera in $12 \%$ polyacrylamide gel. The patterns are presented as follows: 1: A4; 2: A1; 3: A30; 4: C1; 5: A26; 6: A29; 7: A28; 8: M3; 9: M4; 10: M6 and 11: M7.

Samples from Galicia (Spain) contained the M6, M7 and A28. Northern Italian populations were mainly C1, but also contained M3 and M7 (Table 1).

\section{Discussion}

Nearly $68 \%$ of the Brazilian and Uruguayan colonies showed an mtDNA pattern characteristic of South African bees (A4) and $26 \%$ the A1 pattern. The A1 haplotype showed a clinal increase, toward North and Northeast Brazil. Africanized populations sampled from Colombia (Prada, 2004), Venezuela (Clarke et al., 2001), Costa Rica (Segura, 2000) and Mexico (Franck et al., 2001) also showed a predominance of A1 and A4 types, but the A1 pattern was more frequent in all these countries, except in Venezuela, where there is a small excess of A4. Data from Moritz et al. (1994), Garnery et al. (1995) and Franck et al. (2001) show that A4 is more frequent in the South African populations, whereas A1 increases in frequency toward Northern Africa. The higher frequency of A1 and A4 haplotypes toward northern and southern latitudes, respectively, could be attributed to selection, although there are other possible explanations why the trends correspond. 


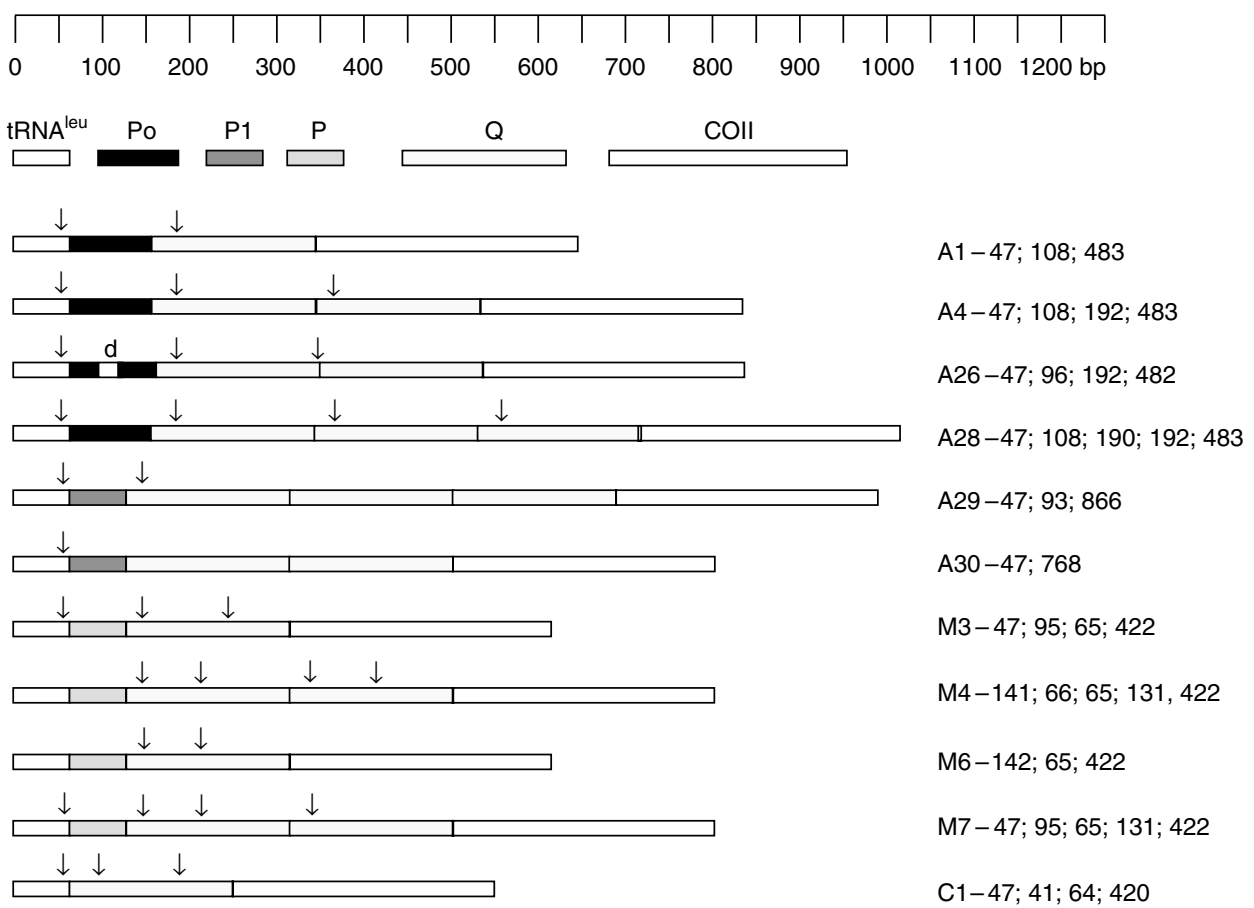

Figure 2 Restriction maps (left) and length of restriction fragments in base pairs (right). Patterns A1, A4, M3, M4, M6, M7 and C1 are according to Garnery et al. (1993) and A26 according to Franck et al. (2001). A28, A29 and A30 are the new A patterns described in this work. Restriction sites are indicated by arrows. $d$ indicates deletion at $\mathrm{P}_{0}$ sequence.

A low proportion of the colonies with A patterns from countries with a history of predominantly Spanish settlement such as Mexico, Venezuela and Costa Rica, may be descended from West European populations. Such patterns were described at low frequencies in Mexico (Clarke et al., 2001) even before the arrival of the Africanized swarms. Moreover, rare M haplotypes (very common in Spain) are still observed in countries such as Costa Rica (Segura, 2000) and Mexico (Clarke et al., 2001; Franck et al., 2001). However, on the basis of the great increase in the frequency of $\mathrm{A}$ haplotypes with the Africanization process, most of the colonies with A pattern must have originated from the introduction of African bees to Brazil in the 1950s.

A few Africanized colonies from Uruguay exhibited a different EcoRI European pattern with a probable origin in Portugal (Diniz et al., 2003). This 'Portuguese' pattern was also found in some Brazilian regions (MA Del Lama, unpublished data). These colonies had A29 and A30 patterns. These two haplotypes have the P1 sequence with a $15 \mathrm{bp}$ deletion, also found in the bees of Iberian Peninsula (Garnery et al., 1995; De la Rúa et al., 1998, 2001a; Franck et al., 2001) and Namibia (Franck et al., 2001). This finding sustains the assumption of an Iberian origin for some of the A haplotypes in America.

The A1 pattern observed in American populations is present in the scutellata subspecies of Southern Africa, the intermissa from Northern Africa, and also the iberiensis subspecies of Iberian Peninsula. It could, therefore, have a double origin in America, either from the Iberian Peninsula or via the introduction of $A . \mathrm{m}$. scutellata into Brazil in 1956. Sheppard et al. (1999) proposed an Iberian intermissa origin for composite haplotype (including the A1 pattern) found in Argentina.
A South African origin of the A1 pattern found in Argentina is also possible. This proposal is supported by evidence such as the small number of patterns on the continent before the expansion of the Africanized swarms, the great increase in these patterns after the Africanization process, and, despite the Iberian settling of the Americas, the rare incidence Iberian patterns in these bees. If the A1 haplotype in the southern part of the continent is distinct from that established in the northern populations up to Mexico, it would imply that the A1 pattern of the American colonies would not have an African origin (via scutellata). The identification of the real A1 origin in South and Central American bees, therefore, requires further study on new mtDNA polymorphisms that could discriminate between Iberian and South African A1 haplotypes.

The few ligustica and the lack of mellifera patterns in regions where the Africanized swarms have established make evident the substitution of European genes by African genes. This change has been favored by such factors as (i) the faster growth rate of African colonies, (ii) nest usurpation, in which African swarms invade European colonies and replace the resident queens and (iii) the selective advantage of Africanized bees over European bees either by their higher colonizing ability or by their superior ability to survive in the neotropical environment (Schneider et al., 2004). In Chile, for example, where the Africanized swarms have not yet been established, because of geographic barriers such as the Andes Mountains, A. m. mellifera comprises nearly $42 \%$ of the mtDNA, the remaining colonies have an A. m. ligustica ancestry (Del Lama et al., 2004).

A significant contribution of European genes in the Africanized bee populations of the Americas has 

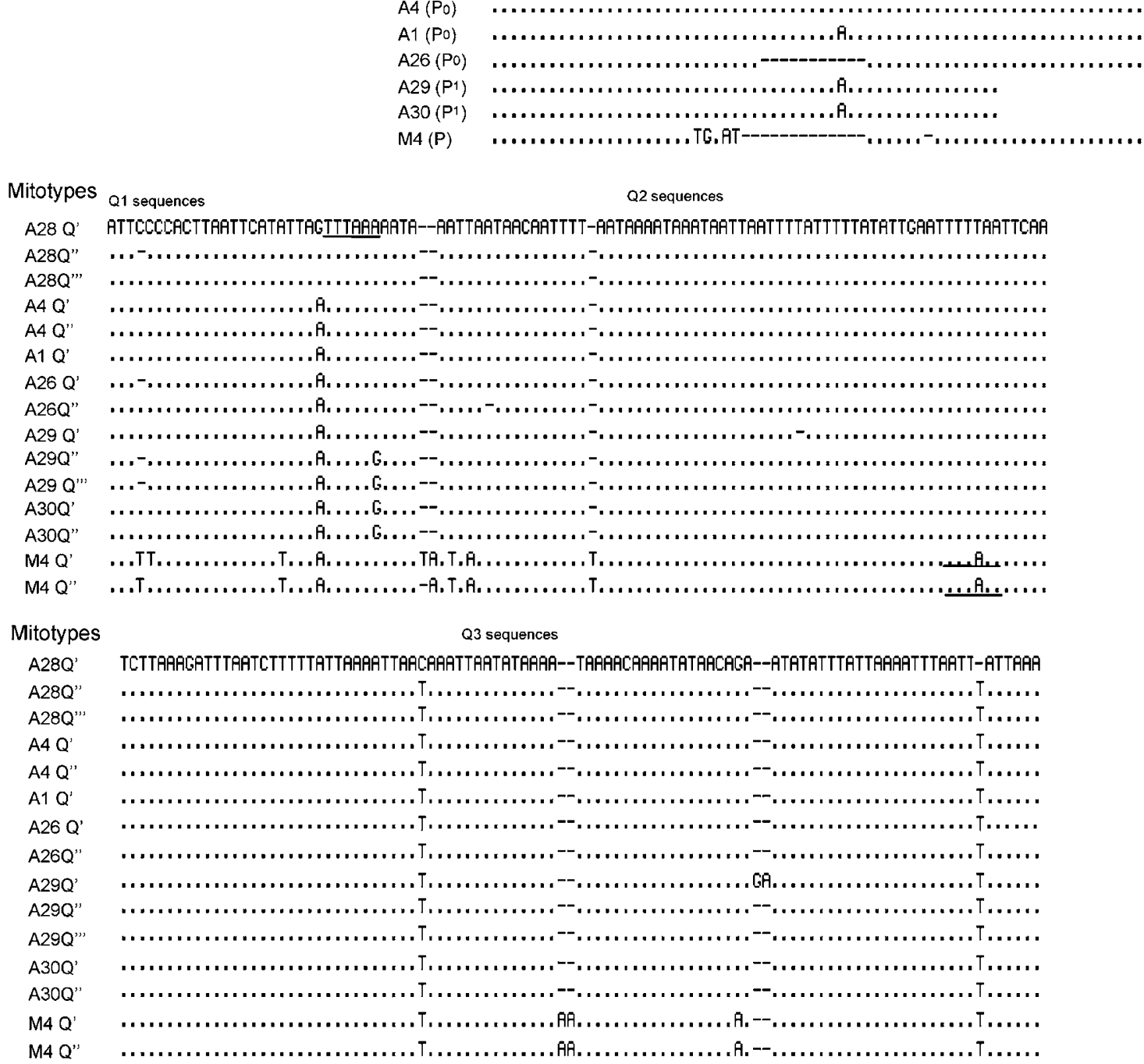

Figure $3 \mathrm{P}$ sequences $\left(\mathrm{P}_{0}, \mathrm{P}\right.$ or $\left.\mathrm{P}_{1}\right)$ and $\mathrm{Q}$ sequences (present as $\mathrm{Q}^{\prime}, \mathrm{Q}^{\prime \prime}$ and $\mathrm{Q}^{\prime \prime \prime}$ according to the additional duplications of the $\mathrm{Q}$ sequence) of the COI-COII region. Insertion/deletion are indicated by dashes. DraI restriction sites are underlined. Dots indicate identical nucleotides.

previously been revealed by allozymes (Lobo et al., 1989; Del Lama et al., 1990) or by nuclear DNA polymorphisms (Suazo et al., 1998; Hall and McMichael, 2001). Although Del Lama et al. (1990) and Diniz et al. (2003) detected $20-30 \%$ of the Mdh M allele in Brazilian samples, no Africanized colony from Brazil had the M haplotype, even though $A$. m. mellifera introductions were made in Brazil by German immigrants during the 19th century. Moreover, among the 50 colonies analyzed in Uruguay, only one exhibited the M4 haplotype. Therefore, our results point to an asymmetry between nuclear and cytoplasmic markers. According to Hall and McMichael (2001), after the hybridization of the African bees with the European resident bees, subsequent selection could eliminate most of the European genes, but neutral alleles, such as some nuclear markers could remain at detectable frequencies.

The M6 pattern showed by Galician samples was also observed in French and Southern Spanish populations of the mellifera subspecies (Franck et al., 1998, 2001), whereas M7 is the most common in Spanish populations. The presence of A28 is in accordance with previous data about some A mitotypes in Iberian populations (Garnery et al., 1993; Franck et al., 1998, 2001). The M7 pattern in Italian samples was also described by Franck et al. (2000), demonstrating the presence of two highly divergent lineages $(\mathrm{C}$ and $\mathrm{M})$ in Italy.

The origin of the A1 haplotype African or Iberian Peninsula remains an open question. The clinal A1 pattern opens new perspectives for the use of other mitochondrial genes. Such new polymorphisms will be able to identify asymmetric gene flow and contribute to a more complete understanding of the genetic composition and genetic structure of the Africanized bee populations.

\section{Acknowledgements}

We thank Isabel Cristina de Godoy and Suzy Coelho for their technical assistance. Two anonymous referees made useful suggestions that improved the paper. We thank 


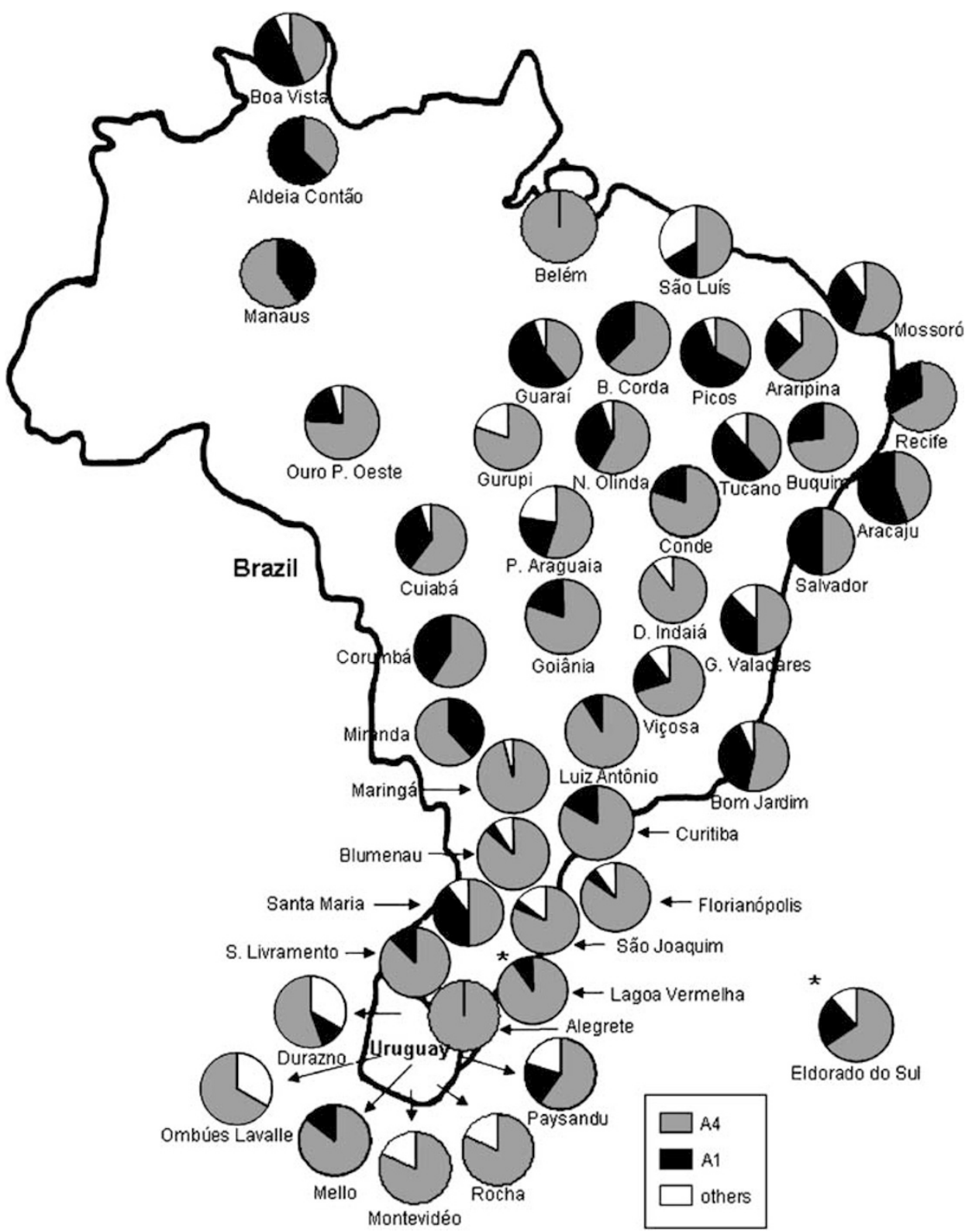

Figure 4 Distribution of A1 and A4 mitotypes for COI-COII region of A. mellifera in the countries analyzed. Pie charts indicate the relative frequencies of the mitochondrial patterns at each sampled locality.

the beekeepers that cordially provided the honeybee samples. This study was supported by 'Fundação de Amparo à Pesquisa do Estado de São Paulo' (Fapesp 03/06342-9) and 'Conselho Nacional de Desenvolvimento Científico e Tecnológico' (CNPq).

\section{References}

Ayres M, Ayres Júnior M, Ayres DL, Santos AS (2003). BioEstat 3.0. Aplicações estatísticas nas áreas das ciências biológicas e médicas. Sociedade Civil Mamirauá, Brasília CNPq: Belém. Clarke KE, Oldroyd BP, Javier J, Quezada-Euán G, Rinderer TE (2001). Origin of honeybees (Apis mellifera L.) from the Yucatan peninsula inferred from mitochondrial DNA analysis. Mol Ecol 10: 1347-1355.

De la Rúa P, Galián J, Serrano J, Moritz RFA (2001a). Genetic structure and distinctness of Apis mellifera L. populations from the Canary Islands. Mol Ecol 10: 1733-1742.
De la Rúa P, Galián J, Serrano J, Moritz RFA (2001b). Molecular characterization and population structure of the honeybees from the Balearic Islands (Spain). Apidologie 32: 417-427.

De la Rúa P, Serrano J, Galián J (1998). Mitochondrial DNA variability in the Canary Islands honeybees (Apis mellifera L.). Mol Ecol 7: 1543-1547.

Del Lama MA, Lobo JA, Soares AEE, Del Lama SN (1990). Genetic differentiation estimated by isozymic analysis of Africanized honeybee populations from Brazil and from Central America. Apidologie 21: 271-280.

Del Lama MA, Souza RO, Durán XAA, Soares AEE (2004). Clinal variation and selection on $\mathrm{MDH}$ allozymes in honeybees in Chile. Hereditas 140: 149-153.

Diniz NM, Soares AEE, Sheppard WS, Del Lama MA (2003). Genetic structure of honeybee populations from Southern Brazil and Uruguay. Gen Mol Biol 26: 47-52.

Franck P, Garnery L, Celebrano G, Solignac M, Cornuet JM (2000). Hybrid origins of honeybees from Italy (Apis mellifera ligustica) and Sicily (Apis mellifera sicula). Mol Ecol 9: 907-921. 
Franck P, Garnery L, Loiseau A, Oldroyd BP, Hepburn HR, Solignac M et al. (2001). Genetic diversity of the honeybee in Africa: microsatellite and mitochondrial data. Heredity 86: 420-430.

Franck P, Garnery L, Solignac M, Cornuet JM (1998). The origin of West European subspecies of honeybees (Apis mellifera): new insights from microsatellite and mitochondrial data. Evolution 52: 1119-1134.

Garnery L, Cornuet JM, Solignac M (1992). Evolutionary history of the honey bee Apis mellifera inferred from mitochondrial DNA analysis. Mol Ecol 1: 145-154.

Garnery L, Mosshine EH, Oldroyd BP, Cornuet JM (1995). Mitochondrial DNA variation in Moroccan and Spanish honey bee populations. Mol Ecol 4: 465-471.

Garnery L, Solignac M, Celebrano G, Cornuet JM (1993). A simple test using restricted PCR-amplified mitochondrial DNA to study the genetic structure of Apis mellifera L. Experientia 49: 1016-1020.

Hall HG, McMichael MA (2001). Frequencies of restriction fragment-length polymorphisms indicate that neotropical honey bee (Hymenoptera: Apidae) populations have African and West European origins. Ecol Pop Biol 94: 670-676.

Hall HG, Muralidharan K (1989). Evidence from mitochondrial DNA that African honeybees spread as continuous maternal lineages. Nature 339: 211-213.

Hall HG, Smith DR (1991). Distinguishing African and European honeybee matrilines using amplified mitochondrial DNA. Proc Natl Acad Sci 88: 4548-4552.

Lobo JA, Del Lama MA, Mestriner MA (1989). Population differentiation and racial admixture in the Africanized honeybee (Apis mellifera L.). Evolution 43: 794-802.
Moritz RFA, Cornuet JM, Kryger P, Garnery L, Hepburn HR (1994). Mitochondrial DNA variability in South African honey bees (Apis mellifera L.). Apidologie 25: 169-178.

Prada CFQ (2004). Estrutura genética das populações de abelhas africanizadas (Apis mellifera L.) da Colômbia estimada através de marcadores nucleares e mitocondriais. MSc Thesis, Universidade Federal de São Carlos, SP, Brazil.

Rotta IT (1999). Análise aloenzimática, morfométrica e dos padrões do DNA mitocondrial das abelhas africanizadas do Brasil. PhD Thesis, Universidade Federal de São Carlos, SP, Brazil.

Schneider SS, DeGrandi-Hoffman G, Smith DR (2004). The African honey bee: factors contributing to a successful biological invasion. Annu Rev Entomol 49: 351-376.

Segura JAL (2000). Highly polymorphic DNA markers in an Africanized honey bee population in Costa Rica. Gen Mol Biol 23: 317-322.

Sheppard WS, McPheron BA (1991). Ribosomal DNA diversity in Apidae. In: Smith DR (ed). Diversity of the Genus Apis. Westview: Boulder, CO. pp 89-102.

Sheppard WS, Rinderer TE, Garnery L, Shimanuki H (1999). Analysis of Africanized honey bee mitochondrial DNA reveals further diversity of origin. Gen Mol Biol 22: 73-75.

Smith DR, Taylor OR, Brown WM (1989). Neotropical Africanized honey bees have African mitochondrial DNA. Nature 339: 213-215.

Suazo A, McTiernan R, Hall HG (1998). Differences between African and European honey bees (Apis mellifera L.) in random amplified polymorphic DNA (RAPD). J Hered 89: 32-36. 